\title{
RELIC CLINOPYROXENES OF PALEOZOIC GREENSTONES OF THE TAMBA AND MIKABU TERRANES, SOUTHWEST JAPAN
}

\author{
Mrtsuo Hashimoto
}

National Science Museum, Tokyo

\begin{abstract}
Electron probe microanalyses of relic clinopyroxenes of Paleozoic greenstones from the Tamba district, southwest Japan, suggest that the original rocks were derivatives of various types of magma, ranging from tholeiite through normal alkali to peralkali basalts. On the other hand, bulk chemical analyses of rocks indicate that they would have been mostly of the alkali basalt series. The discrepancy between the pyroxene chemistry and the bulk composition of rocks may have resulted from the chemical changes which the greenstones have suffered during the metamorphism.

Similar study on the relic clinopyroxenes of the Mikabu Green Rocks showed that the rocks were derived from the tholeitic magmas. The bulk analyses of the Mikabu rocks also give the same conclusion.
\end{abstract}

\section{INTRODUCTION}

Chemical analyses of Paleozoic greenstones from some areas of southwest Japan suggest that the original rocks would have been largely basalts and derivatives of various types of magma (Uchida, 1967; Tanaka, 1970; Hashimoto et al., 1970; Suzuki et al., 1971; Shiida et al., 1971). But it is questionable whether the rocks have retained their original composition, because they have usually suffered metamorphism whose grade ranges from the pumpellyite to the epidote-actinolite facies. Particularly the changes of amounts and ratios of alkalies would seriously affect the conclusion based on the bulk chemical analyses of such metamorphosed greenstones.

On the other hand, clinopyroxenes of the original igneous rocks have been commonly preserved in a fresh state when the metamorphic grade did not reach that of the actinolite zone. Chemical composition of these relic clinopyroxenes may also give clues as to the nature of magmas from which the original rocks of greenstones were derived.

The present writer showed that the relic clinopyroxenes of the Sangun metamorphic rocks of the Katsuyama district were comparable with those of alkali basalts in respect to their $\mathrm{Ca} / \mathrm{Fe} / \mathrm{Mg}$ ratios inferred from the optical properties (Hashimoto, 1964, 1968). Similar studies have been made on Paleozoic greenstones of other terranes (Suzuki, 1967; Kanisawa, 1971; Hashimoto, 1971).

The clinopyroxenes, however, frequently show the hour-glass extinction and the purplish color under the microscope. Therefore they may contain appreciable amounts 
of $\mathrm{TiO}_{2}$. It is difficult to estimate chemical composition of such titaniferous clinopyroxenes from their optical properties. So the direct chemical analysis is desirable.

The electron proble microanalyses were made on relic clinopyroxenes of greenstones in the Upper Paleozoic Tamba and Mikabu terranes of southwest Japan. This paper gives the results and some remarks on the magmas from which the original igneous rocks of these greenstones were derived.

The analytical work was done in the electron microprobe laboratory of Department of Geology, Kanazawa University. The writer wishes to express his sincere thanks to Prof. M. Yamasaki, Prof. S. Banno and students of the department for their kind help and suggestions. Thanks are also due to Dr. N. Kashima and Dr. Y. Saito for their intimate cooperation in the geologic part of this study.

\section{Relic Glinopyroxenes of the TAMBA District}

The Upper Paleozoic (largely Permian) formations are widely exposed in the Tamba district of Kyoto Prefecture. Shale and sandstone are predominant in the sediments, though chert and greenstone are intercalated not infrequently. The outlines of gelogy, petrography, chemistry and metamorphism are given in the previous papers (Hashimoto and Saito, 1970; Hashimoto et al., 1970). Greenstones are weakly metamorphosed basalts, diabase and basic pyroclastic rocks. The main primary minerals of these greenstones are plagioclase and clinopyroxene. Most of the plagioclase have been recrystallized into sodic variety which is associated with pumpellyite and/or epidote. But the clinopyroxenes have not suffered replacement, excluding those in the rocks of the epidote-actinolite zone.

Relic clinopyroxenes from 10 nonporphyritic basalts and microgabbros showing ophitic or subophitic texture were analysed by means of the electron probe microanalyser, using the oxide standards except the synthesized $\mathrm{CaMgSi}_{2} \mathrm{O}_{6}$ for $\mathrm{CaO}$. The analyses given in Table 1 are the averaged compositions of a few clinopyroxene grains in each specimen. Fig. 3 shows the localities of greenstones whose relic clinopyroxenes were analysed. Most of the analysed pyroxenes are augite and salite and those which are characteristic of alkali basalt in respect to the $\mathrm{Ca} / \mathrm{Fe} / \mathrm{Mg}$ ratios. Some of them contain

Table 1. Averaged electron probe partial analyses of relic clinopyroxenes of the Tamba district

\begin{tabular}{|c|c|c|c|c|c|c|c|c|c|c|}
\hline & 1 & 2 & 3 & 4 & 5 & 6 & 7 & 8 & 9 & 10 \\
\hline $\mathrm{SiO}_{2}$ & 43.99 & 52.59 & 51.78 & 47.77 & 52.44 & 49.50 & 50.00 & 49.07 & 52.58 & 52.74 \\
\hline $\mathrm{TiO}_{2}$ & 4.51 & 0.68 & 0.48 & 3.26 & 0.60 & 1.35 & 0.94 & 1.83 & 0.52 & 0.47 \\
\hline $\mathrm{Al}_{2} \mathrm{O}_{3}$ & 8.93 & 3.14 & 2.03 & 5.30 & 2.60 & 5.37 & 4.10 & 4.13 & 2.24 & 2.24 \\
\hline $\mathrm{FeO}^{*}$ & 8.44 & 7.83 & 7.24 & 10.23 & 8.74 & 7.29 & 7.14 & 10.22 & 8.67 & 9.96 \\
\hline $\mathrm{MnO}$ & - & $-\cdots$ & 0.21 & - & - & 0.12 & - & - & - & - \\
\hline $\mathrm{MgO}$ & 10.57 & 15.72 & 16.54 & 11.10 & 15.54 & 14.80 & 16.20 & 14.01 & 15.79 & 16.16 \\
\hline $\mathrm{CaO}$ & 23.98 & 21.98 & 20.23 & 23.02 & 21.66 & 20.58 & 20.37 & 20.34 & 21.46 & 19.25 \\
\hline $\mathrm{Na}_{2} \mathrm{O}$ & $\ldots$ & - & 0.20 & - & - & 0.34 & - & - & - & - \\
\hline $\begin{array}{l}\text { Numbers of } \\
\text { analysed grains }\end{array}$ & 3 & 3 & 2 & 3 & 3 & 1 & 3 & 4 & 3 & 3 \\
\hline Specimen No. & 6881701 & 6881709 & 6882001 & 6891808 & 6892010 & 68121102 & 68121109 & 68121203 & 68121304 & 6951306 \\
\hline
\end{tabular}

* Total iron as $\mathrm{FeO}$ 
appreciable amounts of $\mathrm{TiO}_{2}$ along with $\mathrm{Al}_{2} \mathrm{O}_{3}$, as expected from the microscopic observation. Composition of such pyroxenes is not sufficiently illustrated by the pyroxene quadrilateral.

Kushiro (1960) showed that the ratio $\mathrm{Ti} / \mathrm{Al}$ of igneous clinopyroxenes varies in relation to the magma series to which their host rocks belong. Clinopyroxenes of tholeiite are relatively poor in both $\mathrm{Ti}$ and $\mathrm{Al}$, while those of feldspathoidal rocks are rich in the two elements. Pyroxenes of fedlspathoid-free alkali rocks are intermediate between the above-mentioned two groups.

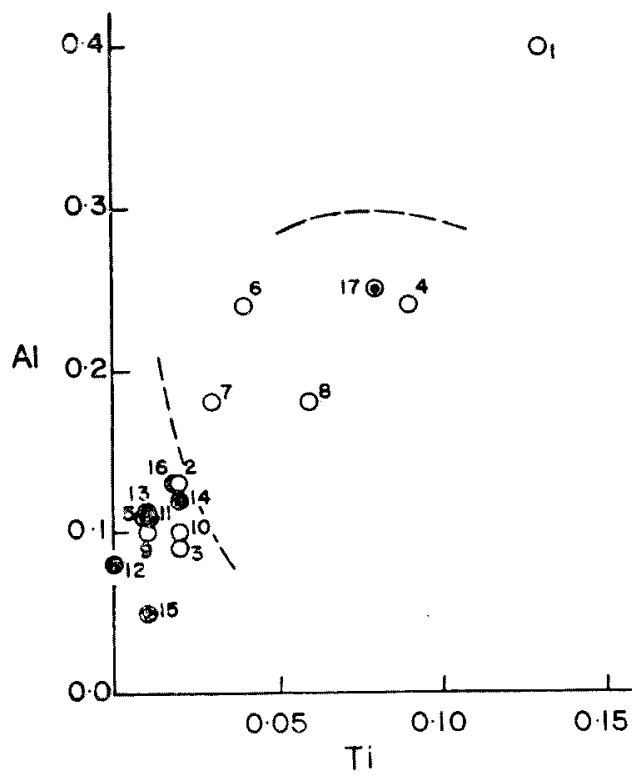

Fig. 1. Ti-Al plots of relic clinopyroxenes of Paleozoic greenstones from the Tamba (open circle) and Mikabu (solid circle) terranes of southwest Japan. Numbers correspond to the analyses of Tables 1 and 2. For two pyroxenes Nos. 15 and 16 , numbers of $\mathrm{Al}^{\mathrm{IV}}$ are plotted. Broken lines separate the fields of tholeiite (lower left), feldspathoid-free alkali basalt (middle) and feldspathoid-bearing alkali basalt (upper), after Kushiro (1960). Double circle represents the clinopyroxene of the Futaiwa formation.
Fig. 1 illustrates the Ti-Al relation of the studied clinopyroxenes of the Tamba greenstones (Nos. 1 to 10). The plots fall in all the fields of Kushiro's diagram.

According to LeBas (1962), the weight percentages of $\mathrm{SiO}_{2}$ and $\mathrm{Al}_{2} \mathrm{O}_{3}$ in igneous clinopyroxenes change antipathetically to each other. The $\mathrm{SiO}_{2}$ content decreases with increasing $\mathrm{Al}_{2} \mathrm{O}_{3}$ as the type of magma varies from tholeiite through normal alkali to peralkali basalts. Fig. 2 shows the Le Bas' plots of the analysed relic pyroxenes of the Tamba greenstones (Nos. 1 to 10 ). In this diagram, too, the composition field of the Tamba clinopyroxenes covers all the fields of tholeiitic to peralkali pyroxenes.

The regional distribution of magma

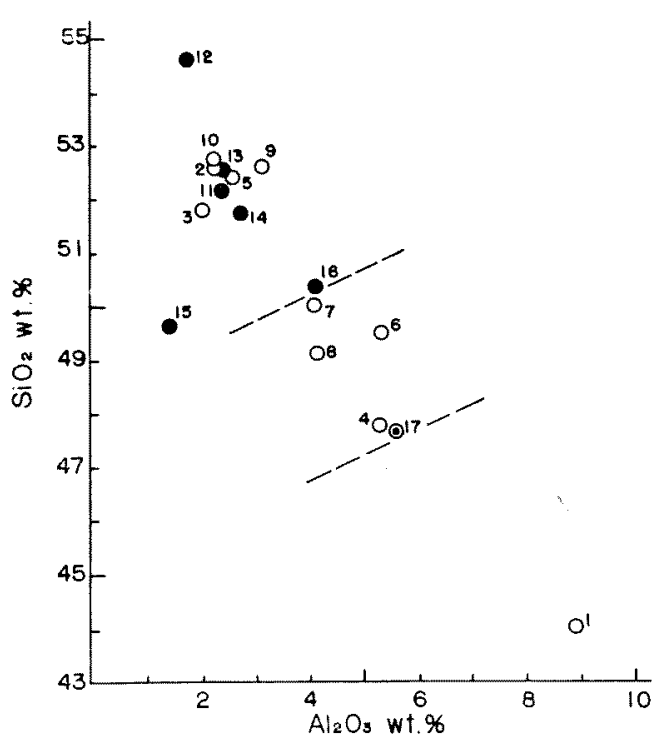

Fig. 2. $\mathrm{SiO}_{2}-\mathrm{Al}_{2} \mathrm{O}_{3}$ relation of relic clinopyroxenes of Paleozoic greenstones from the Tamba and Mikabu terranes. Symbols have the same meanings as in Fig. 1. Broken lines separate the fields of tholeite (upper), normal alkali basalt (middle) and peralkali basalt (lower), after LeBas (1962). That the plot of pyroxene No. 15 is deviated from the general trend may be due to its high content of iron. 
types inferred from the pyroxene chemistry of greenstones in the Tamba district is shown in Fig. 3. No regular trend of distribution is observed. Theoleiite and normal alkali basalt occur intermingling with each other. Furthermore, rocks of the tholeiite and peralkaline basalt magma series are found at the localities very close to one another (Nos. 2 and 1).

On the other hand, as stated in the previous paper (Hashimoto et al., 1970), chemical analyses of carefully selected 14 greenstones from this district suggested that the original igneous rocks were mostly of alkali basalt series. Special care was taken in selecting specimens for analysis so as to get the rocks which were originally holocrystalline with little glassy mesostasis and

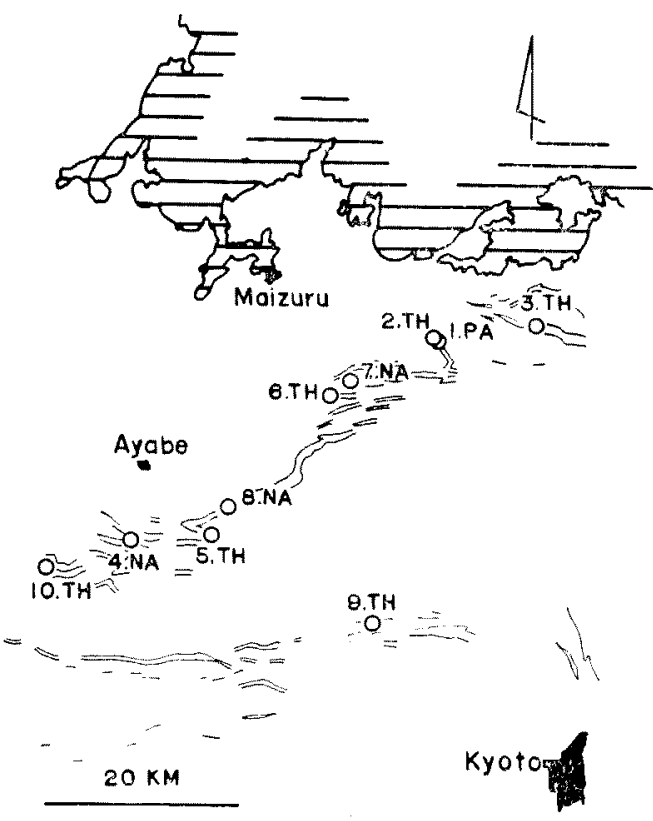

Fig. 3. Distribution of the analysed relic clinopyroxenes in the Tamba district. Numbers correspond to the analyses of Table 1. TH: tholeite, NA: normal alkali basalt, PA: peralkali basalt. Simplified map after Hashimoto et al. $(1970)$, have the least amygdules and veins filled with secondary minerals. Therefore, the analyses of these greenstones were considered to represent the composition close to those of the original rocks.

Thus the bulk chemical analyses suggest that the magma which effused in the Paleozoic sedimentary basin of the Tamba district were principally of alkali basalt, whereas the chemistry of relic clinopyroxenes shows that the magma types of the original igneous rocks were various, ranging from tholeiite through normal alkali to peralkali basalts.

This discrepancy may have resulted from two causes. One is the fact that the analysed clinopyroxenes were not always those of the analysed greenstones. Some of the analysed greenstones are so fine-grained that they are not suitable for the study of relic clinopyroxenes. On the other hand, the unanalysed host greenstones of the studied clinopyroxenes are not fit for the examination of the bulk composition, because they carry appreciable amounts of recrystallized glassy parts and amygdules or veins filled with secondary minerals. In other words, the samples studied in the pyroxene chemistry and the bulk analysis were not all the same with one another. As a result, the two different kinds of study would have given the different conclusions. In one case, however, the pyroxene chemistry and the bulk analysis are really inconsistent. Pyroxene No. 3 which is that of tholeiite in the Ti-Al diagram of Fig. 1 was separated from rock No. I of the previous report whose plot falls in the alkali basalt field of the $\left(\mathrm{Na}_{2} \mathrm{O}+\mathrm{K}_{2} \mathrm{O}\right)-\mathrm{SiO}_{2}$ and $\mathrm{Al}_{2} \mathrm{O}_{3}$ - $\left(\mathrm{Na}_{2} \mathrm{O}+\mathrm{K}_{2} \mathrm{O}\right)-\mathrm{SiO}_{2}$ diagrams (Hashimoto et al., 1970).

The second cause is the metasomatism 
which the rocks would have suffered. The amounts and ratios of alkalies may have changed at least slightly during the metamorphic recrystallization. Consequently, it is possible that some rocks which were originally tholeiitic have become alkalic or vice versa. But, even in such cases, clinopyroxenes have been chemically unchanged and retain their original nature of the respective types of basalts.

Of the above-mentioned two causes the latter is more probable, because considerable chemical changes are common reported to occur in rocks which suffered low-grade regional or burial metamorphism (e.g Vallance, 1965; Smith, 1968; Cann, 1969; Reed and Morgan, 1971).

\section{Relic Glinopyroxenes of the Mikabu Belt}

The Mikabu belt is located between the Sambagawa and Chichibu belts of southwest Japan. It is characterized by the predominance of plutonic and volcanic rocks of basaltic composition. The rocks are mostly affected by low-grade metamorphism and abundantly contain such minerals as actinolite, chlorite, epidote, glaucophane and pumpellyite. So the rocks are collectively called the Mikabu Green Rocks by Japanese geologists.

Iwasaki (1963) and Nakamura (1970) analysed relic clinopyroxenes of metabasalts from the Mikabu belt. The pyroxene studied by the former came from the eastern part of Shikoku and that of the latter from

Table 2. Analyses of relic clinopyroxenes of the Mikabu and Chichibu terranes

\begin{tabular}{|c|c|c|c|c|c|c|c|}
\hline & $11^{*}$ & $12^{*}$ & $13^{*}$ & $14^{*}$ & 15 & 16 & $17^{*}$ \\
\hline $\mathrm{SiO}_{2}$ & 52.17 & 54.59 & 52.57 & 51.74 & 49.62 & 50.36 & 47.64 \\
\hline $\mathrm{TiO}_{2}$ & 0.30 & 0.00 & 0.46 & 0.55 & 0.44 & 0.72 & 2.47 \\
\hline $\mathrm{Al}_{2} \mathrm{O}_{3}$ & 2.42 & 1.75 & 2.49 & 2.75 & 1.44 & 4.17 & 5.60 \\
\hline $\mathrm{Fe}_{2} \mathrm{O}_{3}$ & - & - & -- & - & 5.14 & 3.67 & - \\
\hline $\mathrm{FeO}$ & $9.63^{* *}$ & $7.93^{* *}$ & $7.39^{* *}$ & $8.25^{* *}$ & 9.46 & 5.52 & $9.21^{* \star}$ \\
\hline $\mathrm{MnO}$ & - & - & 0.22 & 0.19 & 0.28 & 0.17 & 0.22 \\
\hline $\mathrm{MgO}$ & 14.73 & 16.97 & 16.61 & 16.33 & 10.53 & 14.64 & 13.48 \\
\hline $\mathrm{CaO}$ & 21.69 & 20.09 & 21.17 & 20.92 & 20.35 & 19.65 & 21.37 \\
\hline $\mathrm{Na}_{2} \mathrm{O}$ & - & - & 0.14 & 0.24 & 0.27 & 0.79 & 0.15 \\
\hline $\mathrm{K}_{2} \mathrm{O}$ & - & - & - & - & 0.04 & $\operatorname{tr}$ & - \\
\hline $\mathrm{H}_{2} \mathrm{O}_{+}$ & - & - & - & - & 1.44 & 0.60 & - \\
\hline $\mathrm{H}_{2} \mathrm{O}_{-}$ & - & - & - & - & 0.37 & 0.10 & - \\
\hline $\mathrm{P}_{2} \mathrm{O}_{5}$ & - & - & - & - & - & 0.04 & - \\
\hline $\mathrm{NiO}$ & - & - & - & - & - & 0.02 & - \\
\hline $\mathrm{Cr}_{2} \mathrm{O}_{3}$ & - & - & - & - & - & 0.20 & - \\
\hline Total & & & & & 99.38 & 100.65 & \\
\hline $\begin{array}{l}\text { Numbers of } \\
\text { analysed grains }\end{array}$ & 3 & 1 & 4 & 1 & & & 2 \\
\hline Specimen No. & 65081701 & 65082113 & 65082201 & 66031601 & 5807216 & $\begin{array}{c}\text { YN } \\
64010608\end{array}$ & $65081906^{* * *}$ \\
\hline Reference & & & & & $\begin{array}{c}\text { Iwasaki } \\
1963\end{array}$ & $\begin{array}{l}\text { Nakamura } \\
1970\end{array}$ & \\
\hline
\end{tabular}

\footnotetext{
* Electron probe analyses

** Total iron as $\mathrm{FeO}$

*** From the Futaiwa formation
} 
the Toba district, eastern Kii peninsula. The analyses are cited in columns 15 and 16 of Table 2. They are all diopsides poor in both $\mathrm{TiO}_{2}$ and $\mathrm{Al}_{2} \mathrm{O}_{3}$, so they are pyroxenes characteristic of tholeiite, according to Kushiro (1960) and LeBas (1962).

Adtitional 4 analyses were made on relic clinopyroxenes of metabasalts and meta-microgabbros from the Saitaro formation in the Oozu-Nomura district, western Shikoku. As to the geology and petrology of greenstones of this district, the reader may refer to Kashima (1969), Hashimoto and Kashima (1970) and Hashimoto et al. (1970). According to Kashima (1969), the Saitaro formation is geologically correlated with the Mikabu Green Rocks. The results of analysis are listed in columns 11 to 14 of Table 2. All the new analyses also show the chemical characteristics of the tholeiitic clinopyroxene. All the plots for these 6 analysed pyroxenes fall in the fields of tholeiitic ones of Kushiro's and LeBas' diagrams.

On the other hand, bulk chemical analyses of 5 greenstones, including 4 whose relic clinopyroxenes were studied, of the Saitaro formation are poor in alkalies, particularly in $\mathrm{K}_{2} \mathrm{O}$, as compared with the $\mathrm{SiO}_{2}$ and $\mathrm{Al}_{2} \mathrm{O}_{3}$ contents. Their plots fall in the theoleiite field of Kuno's $\left(\mathrm{Na}_{2} \mathrm{O}+\mathrm{K}_{2} \mathrm{O}\right)-$ $\mathrm{SiO}_{2}$ and $\mathrm{Al}_{2} \mathrm{O}_{3}-\left(\mathrm{Na}_{2} \mathrm{O}+\mathrm{K}_{2} \mathrm{O}\right)-\mathrm{SiO}_{2}$ diagrams (Hashimoto et al., 1970). Analyses of the Mikabu greenstones made by the other investigators also show that the original rocks were tholeiitic (e.g. Suzuki et al., 1971). Consequently, in the case of the Mikabu rocks, there is no discrepancy between the pyroxene chemistry and the bulk composition.

Kawachi and Watanabe (1972), however, stated that relic clinopyroxenes from metabasalts of the Mikabu terane of Nagano Prefecture, central Japan, showed chemical features of pyroxenes of normal alkali basalt in Kushiro's and LeBas' diagrams, but pyroxenes of metagabbros intruded into the metabasalts were those of tholeiite. According to them, in the Mikabu Green Rocks only intrusive gabbros would have been the derivatives of tholeiite magma, while extrusive rocks are considered to have been the products of alkali basalt magma.

Clinopyroxene of a greenstone from the Paleozoic Chichibu belt was also analysed for comparison. The specimen came from the Futaiwa formation (probably Lower Permian) of the Oozu-Nomura district (Kashima, 1969). Bulk chemical analysis of the greentone is of alkali basalt (Hashimoto et $a l ., 1970$ ), and the clinopyroxene also is that of normal alkali basalt, as shown in column 17 of Table 2 and Figs. 1 and 2 (No. 17).

\section{Gonalusion}

One of the aims of the writer's study of Paleozoic greenstones is to clarify the variation in time and space of magma types within the sedimentary basins of this age in southwest Japan. Bulk chemical analyses, of course, give much valuable information about the chemical nature of the original igneous rocks and their parental magmas. But the greenstones have been usually affected by metamorphism of the pumpellyite and epidote actinolite facies. Therefore, it is uncertain whether the rocks retain their original chemical compositions.

Accordingly, it would be better to examine relic minerals, particularly clinopyroxene, because it is the only mineral which is preserved in a fresh state in these greenstones. 
This study, though preliminary, shows that some discrepancies are found between the pyroxene chemistry and the bulk analyses of rocks. The discrepancies may have resulted from changes in bulk chemistry which have taken place during the metamorphism.

APPEndix 1. Brief descriptions of the host greenstones of the analysed clinopyroxenes

1. Basalt (6881701) The rock was primarily aphyric basalt being composed of abundant purplish clinopyroxenes, a small amount of minute grains of brown hornblende and some plagioclase laths. The secondary minerals are chlorite, sphene, carbonate and felsic minerals. Albite-chloritecalcite veins cut the rock.

2. Clinopyroxene dolerite (6881709) The rock shows typical ophitic texture and was composed primarily of clinopyroxene, plagioclase and ilmenite. The feldspar and ilmenite are replaced by secondary minerals such as albite (?), clinozoisite and sphene. Chlorite may have been derived from olivine and glassy mesostasis.

3. Clinopyroxene microgabbro (6882001) The primary minerals are plagioclase and clinopyroxene $\left(2 V_{Z}=46^{\circ}, c \wedge Z=39^{\circ}\right)$, showing subophitic texture, and minor ilmenite. The secondary minerals are chlorite, sericite, sphene and minor pumpellyite and calcite. Analysis in Table 3.

4. Basalt (6891808) The primary constituents are equigranular plagioclase, purplish clinopyroxene and glassy mesostasis. Weak flow structure is observed. Albite (?), sericite, chlorite, sphene and calcite are the secondaries. A few amygdules are filled with sericite and chlorite. The rock is strongly infiltrated with hemetitic material.
5. Basalt (6892010) The rock shows intergranular texture consisting primarily of plagioclase, pale purplish clinopyroxene, and probable ilmenite and olivine. The secondary minerals are albite, pumpellyite, sericite, chlorite and sphene.

6. Plagioclase-phyric basalt (68121102) The primary constituents are phenocrysts of plagioclase and the groundmass consisting of plagioclase, clinopyroxene, ilmenite and mesostasis. Albite, pumpellyite, sericite, chlorite and sphene are the secondaries. Albite-pumpellyite veins cut the rock.

7. Basalt (68121109) The primary minerals are plagioclase, clinopyroxene $\left(2 \mathrm{~V}_{Z}=\right.$ $51^{\circ}, c \wedge Z=44^{\circ}$ ) and ilmenite. Albite, pumpellyite, chlorite and sphene occur as the secondary minerals. Thin veinlets of calcite are also observed. Analysis in Table 3.

8. Clinopyroxene microgabbro (6812 1203) Plagioclase (An $\div 30$ ), clinopyroxene $\left(2 \mathrm{~V}_{\mathrm{z}}=51^{\circ}\right.$ to $\left.54^{\circ}\right)$ and ilmenite make a finegrained granular and gabbroid aggregate. Epidote, actinolite, chlorite and sphene are the secondaries. Actinolite replaces relic clinopyroxene at its periphery and along the cleavages and cracks. Analysis in Table 3.

9. Basalt (68121304) Originally the rock was subophitic and composed of plagioclase, pale purplish clinopyroxene and ilmenite. Excluding the pyroxene, the minerals are replaced by the secondary products such as albite, pumpellyite, chlorite, sphene and calcite. Cavities and pseudomorphs after probable olivine are filled with chlorite and calcite. Pumpellyite-calcite veins cut the rock.

10. Basalt (6951306) Plagioclase, clinopyroxene, and probable ilmenite and mesostasis are the primary constituents making the hyalopilitic texture. Albite (?), 
Table 3. Analyses of the host greenstones of the analysed clinopyroxenes (Hashimoto et al., 1970).

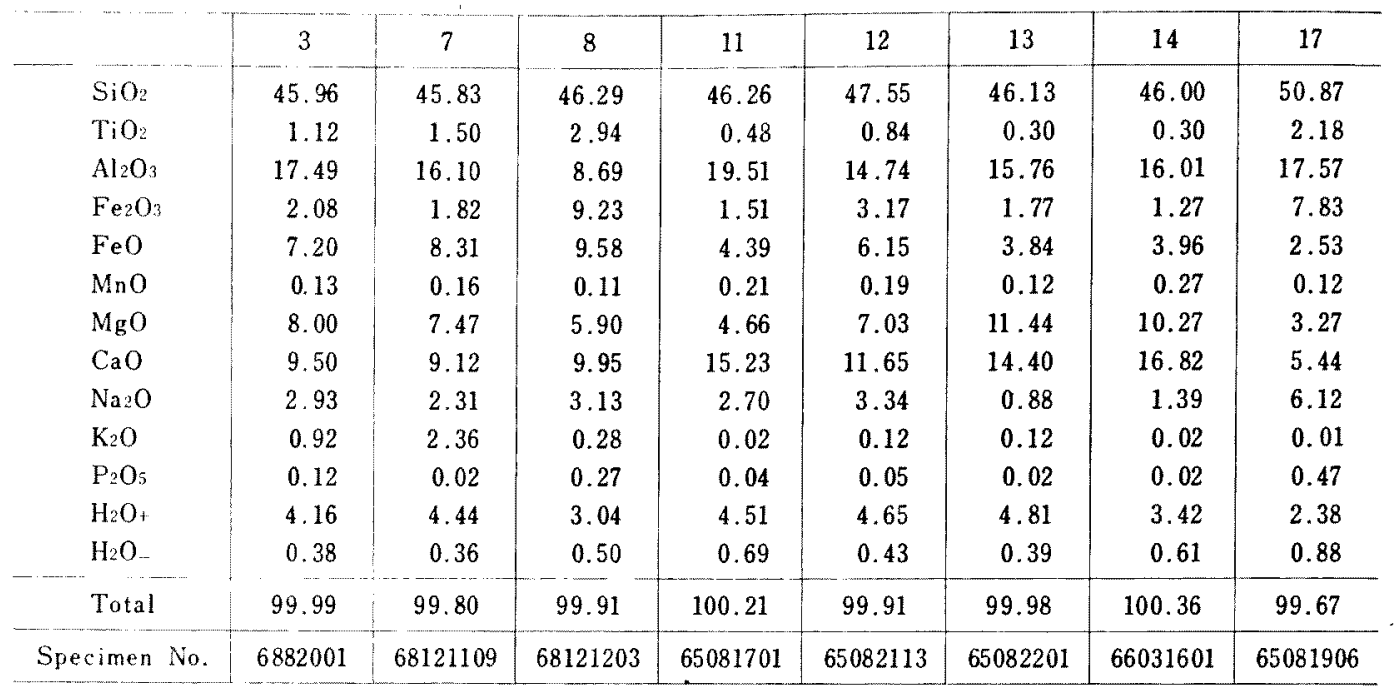

pumpellyite, chlorite and sphene are the secondaries. Chlorite fills distorted amygdules.

11. Clinopyroxene microgabbro $(6508$ 1701) The principal minerals are clinopyroxene $\left(2 V_{Z}=53^{\circ}\right)$ and probable plagioclase. The latter is completely altered into a dense aggregate of unidentified minerals. Actinolite replaces a part of clinopyroxene. Analysis in Table 3 .

12. Clinopyroxene microgabbro (6508 2113) Granular gabbroid rock composed of completely recrystallized plagioclase, clinopyroxene $\left(2 \mathrm{~V}_{\mathrm{z}}=50^{\circ}\right.$ to $\left.51^{\circ}\right)$, minor brown hornblende and leucoxinized ilmenite. The secondary minerals are pumpellyite, epidote, chlorite, calcite, sphene, albite and actinolite-riebeckite. Analysis in Table 3.

13. Clinopyroxene microgabbro $(6508$ 2201) Gabbroid rock primarily composed of plagioclase and clinopyroxene $\left(2 \mathrm{~V}_{Z}=51^{\circ}\right.$ to $53^{\circ}, \mathrm{c} \wedge \mathrm{Z}=40^{\circ}$ ). Analysis in Table 3 .

14. Clinopyroxene microagbbro $(6603$ 1601) Medium-grained granular gabbroid rock. The principal minerals are clinopyro- xene $\left(2 \mathrm{~V}_{Z}=52^{\circ}\right)$ and probable plagioclase. The former is replaced by actinolite. The feldspar is entirely recrystallized into dense aggeragates of unidentified minerals. Chlorite pseudomorphs after probable olivine are rarely observed. Analysis in Table 3.

15. See Iwasaki (1963)

16. See Nakamura (1970)

17. Clinopyroxene microgabbro $(6508$ 1906) Medium-grained gabbroid rock consisting mainly of plagioclase (An $\div 35$ ) clinopyroxene $\left(2 \mathrm{~V}_{z}=53^{\circ}\right)$, ilmenite and apatite. The secondary minerals are pumpellyite, chlorite and sphene. Highly infiltrated by hematitic material. Analysis in Table 3.

Appendix 2. Chemical analyses of the host greenstones of the studied clinopyroxenes are listed in Table 3 .

\section{REFERENCES CITED}

Cann, J.R. (1969), Spilites from the Carlsberg Ridge, Indian Ocean, J. Petrol., 10, 1-19.

Hashimoto, M. (1965), Relic clinopyroxenes in greenschists, J. Geol. Soc. Japan, 71, 470472, (in Japanese with English abstract). (1968), Glaucophanitic metamorphism of the Katsuyama district, Okayama Prefecture, 
Japan, J. Fac. Sci., Univ. Tokyo, Sec. II, 17, 99-162.

(1971), Problems of Paleozoic volcanic rocks of southwest Japan, Mem. Geol. Soc. Japan, 6, 111-119. (in Japanese with English abstract).

and Kashima, N. (1970), Metamorphism of Paleozoic greenstones in the Chichibu belt of western Shikoku, J. Geol. Soc. Japan, 76, 199-204, (in Japanese with English abstract). and Saito, Y. (1970), Metamorphism of Paleozoic greenstones of the Tamba plateau, Kyoto Prefecture, J. Geol. Soc. Japan, 76, 16.

Kashima, N. and Saito, Y. (1970), Chemical composition of Paleozoic greenstones from two areas of southwest Japan, J. Geol. Soc. Japan, 76, 463-476.

Iwasaki, M. (1963), Metamorphic rocks of the KotuBizan area, eastern Sikoku, J. Fac. Sci., Univ. Tokyo, Sec. II, 15, 1-90.

Kanisawa, S. (1971), Basic and intermediate volcanic rocks from the Paleozoic formations in the southern Kitakami mountainland, Japan, J. Japan. Ass. Miner. Petrol. \& Econ. Geol., 65, 247-264.

Kashima, N. (1969), Stratigraphical studies of the Chichibu belt in western Shikoku, Mem. Fac. Sci., Kyushu Univ., Ser. D. 19, 387-436.

Kawachi, Y. and Watanabe, T. (1972), Relic clinopyroxenes from the Sambagawa and Chichibu belts of the Oshika district, Nagano Prefecture, J. Japan. Ass. Miner. Petrol. \& Econ. Geol., 67, 110, (in Japanese with English abstract).

Kushiro, I. (1960), Si-Al relations in clinopyroxenes from igneous rocks, Amer. J. Sci., 258, 548554.

LeBas, M.J. (1962), The role of aluminum in igneous clinopyroxenes with relation to their parentage, Amer. J. Sci., 260, 267-288,

Nakamura, Y. (1970), Petrology of the Toba ultrabasic complex, Mie Prefecture, central Japan, Ph. D. Thesis, Univ. Tokyo.

Reed, J.C., Jr. and Morgan, B.A. (1971), Chemical alteration and spilitization of the Catoctin greenstones, Shenandoh National Park Virginia, J. Geol., 79, 526-548.

Shiida, I., Suwa, K., Sugisaki, R., Tanaka, T. and Shiozaki, H. (1971), Greenstones of the Cretaceous Hitakagawa belt of the Shimanto terrain in the Totsukawa area, Nara Prefecture, central Japan, Mem. Greol. Soc. Japan, 6, 137149, (in Japanese with English abstract).

Smith, R.E. (1968), Redistribution of major elements in the alteration of some basic lavas during burial metamorphism, J. Petrol., 9, 191-219.

Suzuki, T. (1967), Relic clinopyroxenes in the Mikabu greenstones of the Okuki district, Bull. West Japan Branch, Geol. Soc. Japan, 60, 15, (in Japanese with Englishabstract).

, Sugisaki, R. and Tanaka, T. (1971), Geosynclinal igneous activity of the Mikabu Green Rocks of Ozu City, Ehime Prefecture, Mem.Geol. Soc. Japan, 6, 121-136, (in Japanese with English abstract).

Tanaka, T. (1970), Chemical composition of geosynclinal volcanic rocks from the Paleozoic Chichibu group in central Japan, J. Geol. Soc. Japan, 76, 323-335, (in Japanese with English abstract).

Uchida, N. (1967), Chemical composition of tuffs from the Mikabu and Mamba formations, Seikeironso, 6, 3-17, (in Japanese with English abstract).

Vallance, T.G. (1965), On the chemistry of pillow lavas and the origin of spilites, Miner. Mag., $34,471-481$.

\title{
丹波帯および御荷針帯の古生界緑色岩の残留単斜輝石
}

\author{
橋本光男

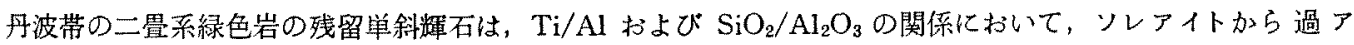 \\ ルカリ玄武岩にいたるいろいろな型の玄武岩の輝石の性質を示す。また，それらの玄武岩型は，規則的な地城 \\ 的分布を示さない。これらのととは，緑色岩の総化学組成が一般にアルカリ岩の組成を示すという，以前に得 \\ られた結論と符合しない。この食い違いは，緑色岩のうけた低度変成作用に際して，総化学組成が変化し，輝 \\ 石のそれが変らなかったために生じたのであうう。 \\ 一方，御荷錊带では，残留単斜輝石の示す玄武岩の型と，岩石の総化学組成加ら推定されるものとの閒に， \\ 今のところ食い違いは認めら机ていない。 \\ Futaiwa 双 岩 Saitaro 才太 郎 Oozu-Nomura 大洲・野村
}

